\title{
PELATIHAN PENYUSUNAN KEGIATAN PEMBELAJARAN PAIKEM INOVATIF BERBASIS 101 METODE GUNA MENINGKATKAN KOMPETENSI PEDAGOGIK GURU MGMP MADRASAH TSANAWIAH SE-KABUPATEN MADIUN
}

\author{
Sigit Ricahyono" ${ }^{1)}$, Samsul Arifin ${ }^{2)}$ \\ Pendidikan Bahasa Inggris, IKIP PGRI MADIUN \\ 1)email: sigitr@gmail.com \\ ${ }^{2)}$ email: samsu10442@gmail.com
}

\begin{abstract}
A professional teacher must be capable of mastering four basic competences namely pedagogical competence, professional competence, sosial competence, and personal competence. The result of observing and interviewing teachers who involve to the Association of Madrasah Tsanawiah Teachers (MGMP) Madiun showed that many of them still need reinforcement and enrinchment on mastering teaching methods of English. Thus, the programme aimed at increasing the pedagogical competence of teachers involving into the MGMP through having worhshop and training to design the teaching procedures implementing 101-based active, creative, efective, joyful, and innovative learning method (PAIKEM-INOVATIF). The programme was held for 5 months started on February 2014 and finished on June 2014. The result of workshop and training showed that process of understanding and practicing the metods run well. Some problems arouse during the programme were (1) the teachers still found difficulties on doing variation of teaching, (2) the teachers still feel clumsy on do peer-teaching using themethods, (3) the teachers still found difficulties on implementing some of the trained methods since the sudents have different learning characterictics. Therefore, it is suggested that the activity should be strengthen by having a programme of Lesson Study.
\end{abstract}

Keywords : PAIKEM-Innovatif Teaching Methods, Workshop and Training.

\section{PENDAHULUAN}

Guru merupakan jabatan profesional yang harus memenuhi kualifikasi tertentu yang meliputi intelkektualitas dan penguasaan disiplin ilmu khusus (Soetjipto dan Kosasi, 2004). Dalam proses pembelajaran, guru tidak hanya berperan sebagai teladan bagi siswa tetapi juga sebagai pengelola pembelajaran. Pemberdayaan komponen-komponen yang ada dalam pembelajaran (bahan, media, metode, sarana prasarana, dan lain-lain) tidak akan berguna dalam mencapai tujuan jika tidak didukung oleh keberadaan guru yang professional, karena guru merupakan unsur manusiawi yang sangat menentukan keberhasilan pendidikan (Bafadal, 2003). Dengan kata lain, efektifitas pembelajaran ditentukan oleh kualitas kemampuan guru (Sanjaya, 2006). Kegagalan guru dalam mengkonstruksi dan mengelola pembelajaran akan mengakibatkan ketidak-berhasilan bagi peserta didik. Selain peserta didik kehilangan minat dan perhatian dalam pembelajaran, mereka juga kehilangan motivasi untuk belajar. Untuk mencapai profesionalitas tersebut, seorang guru dituntut menguasai empat kompetensi yang mencakup kompetensi profesional, kompetensi sosial, kompetensi personal, dan kompetensi pedagogik (Depdiknas, 2005). Kompetensi professional mencakup penguasaan materi pelajaran, landasan dan wawasan kependidikan dan keguruan, proses kependidikan, keguruan dan pembelajaran siswa. Kompetensi sosial mencakup penyesuaikan diri dengan tuntutan kerja dan lingkungan sekitar. Kompetensi personal mencakup penampilan sikap yang positif terhadap keseluruhan tugas dalam upaya untuk menjadikan dirinya sebagai panutan dan teladan bagi para siswanya. Sedang kompetensi pedagogik mencakup pemahaman terhadap peserta didik seperti membantu siswa menyadari kekuatan dan kelemahan diri, membantu siswa menumbuhkan kepercayaan diri, keterbukaan terhadap pendapat siswa, sikap sensitif terhadap kesukaran peserta didik, perancangan 
pembelajaran, seperti perumusan indikator, ketepatan materi, penggunaan media, mengorganisasikan urutan materi, ketepatan alat evaluasi, dan kemampuan mengembangkan potensi peserta didik. Ditambahkan, seorang guru juga harus menguasai keterampilan dasar mengajar yang meliputi (1) Keterampilan membuka dan menutup pelajaran (introductory dan closure skills); (2) Keterampilan mengelola kelas (classroom management); (3) Keterampilan memberi penguatan (reinforcement); (4) Keterampilan mengajar kelompok kecil dan perorangan (group and individual teaching); (5) Keterampilan bertanya (questioning); (6) Ketrampilan menjelaskan pelajaran (explaining); (7) Ketrampilan mengadakan variasi (teaching variation); dan (8) Ketrampilan penilaian (assessing) (Wardani, 1997; Saud, 2009).

Untuk meningkatkan berbagai kompetensi guru, pemerintah telah melakukan berbagai upaya secara nyata dan berkelanjutan. Berbagai upaya tersebut diantanya (1) pengadaan diklat kepribadian (personality training) dalam artian pemberian proses akuisisi dari pengetahuan (knowledge), keterampilan (skill), dan sikap (attitude) yang mampu mendorong siswa mencapai tujuan individual dan kelompok saat ini dan di masa depan dalam melaksanakan berbagai tugas dan jabatan dengan baik (Bambrough, dalam Mendiknas 2003); (2) pemberian beasiswa/menyekolahkan guru ke tingkat yang lebih tinggi untuk menambah pengetahuan guru sehingga dapat meningkatkan kompetensi guru; (3) Penerapan lesson study dalam artian belajar dan mengobservasi guru lain yang memiliki kompetensi lebih tinggi dengan harapan dapat belajar dan termotivasi untuk leboh baik; dan (4) pemberian berbagai pelatihan dan workshop baik secara terpusat maupun di daerah.

Upaya pemerintah lainnya untuk meningkatkan kompetensi guru adalah mengintensifkan berbagai kegiatan dalam Kelompok Kerja Guru (KKG) dan Musyawarah Guru Mata Pelajaran (MGMP). KKG dan MGMP merupakan mitra kerja Lembaga Penjaminan Mutu Pendidikan (LPMP), dalam meningkatkan mutu pendidikan yang bertujuan meningkatkan profesionalisme guru anggota forum tersebut. Melalui forum KKG/MGMP diharapkan akan terjadi sharing informasi antara guru dari satu sekolah dengan guru dari sekolah lainnya. Selain itu, KKG dan MGMP diharapkan bisa menjadi wadah tukar menukar pengalaman para guru agar terjadi saling penguatan dalam peningkatan mutu proses pembelajaran di kelas masing-masing. Diharapkan pula terjadi inovasi-inovasi guru dalam mengembangkan alat peraga dan model-model pembelajaran pada setiap satuan pendidikan. Keberadan wadah tersebut juga diharapkan mampu mendukung peningkatan kreativitas guru dalam pengelolaan pembelajaran yang bermuara pada terciptanya suasana pembelajaran yang kondusif, inovatif, aktif, kreatif, efektif, dan menyenangkan. Dengan demikian kompetensi guru akan tumbuh dan berkembang seiring dengan meningkatnya aktivitas $\mathrm{KKG} / \mathrm{MGMP}$ di masing-masing Kabupaten/Kota.

Mengamati dan mempelajari kompetensi guru yang tergabung dalam Kelompok Musyawarah Guru Mata Pelajaran (MGMP) Madrasah Tsanawiah se-Kabupaten Madiun, dapat dikatakan bahwa guru yang tergabung dalam MGMP tersebut masih memerlukan adanya pelatihan metode pembelajaran untuk meningkatkan kompetensi pedagogiknya. Hasil interview dan wawancara juga menunjunkkan bahwa pengetahuan guru tentang metode pembelajaran mempunyai andil cukup besar dalam menentukan keberhasilan kegiatan pembelajaran, ataupun mengatasi berbagai masalah di kelas. Kemampuan anak didik ditentukan oleh ketepatan guru dalam memilih dan menggunakan metode yang sesuai dengan karakteristik mereka, materi pembelajaran, dan tujuan pembelajaran. Dengan memahami berbagai metode pembelajaran, guru dapat melakukan variasi dalam kegiatan pembelajaran. Dengan adanya variasi, siswa tidak akan merasa tertekan selama pembelajaran, siswa tidak akan bosan selama pembelajaran, siswa bisa fokus terhadap pelajaran, siswa lebih mudah menguasai kompetensi pembelajaran, sehingga tujuan pembelajaran akan tercapai. Selain itu, dengan adanya variasi dalam kegiatan pembelajaran, guru akan lebih mudah mengelola kelas karena berbagai aktivitas dalam metode akan bersifat learner-centered sehingga siswa akan lebih banyak berfokus pada kegiatan pembelajaran daripada menghiraukan materi. Selain itu, dengan adanya variasi metode pembelajaran, gaya mengajar guru di kelas akan berubah dari banyak punishment menjadi penggunaan pendekatan personal dan kelompok berbasis reward. Gaya mengajar ini akan memotivasi siswa dalam mencapai tujuan pembelajarn dengan menyenangkan dan secara tidak sadar juga akan meningkan kemampuan guru dalam memahami psikologis siswa. Secara lambat 
laun, kreatifitas guru dalam merancang suatu pembelajaran yang aktif, efektif, menyenangkan, dan inovatif akan muncul dan mampu berkembang. Sehubungan dengan paparan analisis situasi tersebut, tujuan program IPTEK Bagi Masyarakat $\left(\mathrm{I}_{b} \mathrm{M}\right)$ dirumuskan sebagai berikut:

a. Meningkatkan kompetensi pedagogik guru yang tergabung dalam Kelompok Musywarah Guru Mata Pelajaran (MGMP) Madrasah Tsanawiah (MTs) Se-Kabupaten Madiun dengan mengadakan pelatihan penyusunan kegiatan pembelajaran aktif, kreatif, efektif, menyenangkan, dan inovatif berbasis 101 metode;

b. Meningkatkan kompetensi pedagogik guru yang tergabung dalam Kelompok Musywarah Guru Mata Pelajaran (MGMP) Madrasah Tsanawiah (MTs) Se-Kabupaten Madiun dengan mengadakan pembimbingan penyusunan kegiatan pembelajaran aktif, kreatif, efektif, menyenangkan, dan inovatif berbasis 101 metode.

\section{METODE PELAKSANAAN}

\section{a. Tempat, Waktu, dan Subjek IPTEK Bagi Masyarakat $\left(\mathrm{I}_{b} \mathbf{M}\right)$}

Kegiatan IPTEK Bagi Masyarakat $\left(\mathrm{I}_{b} \mathrm{M}\right)$ ini dilakukan di area kabupaten madiun yang mencakup 15 kecamatan. Dalam pelaksanaannya, kegiatan ini difokuskan di daerah Jiwan, tepatnya MTsN Bibrik Kecamatan Jiwan. Kegiatan pengabdian ini dilakukan selama 5 bulan, mulai bulan Februari 2014 sampai dengan Juni 2014. Subjek abdimas ini adalah seluruh guru bahasa inggris anggota MGMP Madrasah Tsanawiah (MTs) sekabupaten Madiun yang tersebar dalam 15 kecamatan yaitu balerejo, jiwan, pilangkenceng, dagangan, kare, kebonsari, saradan, dolopo, sawahan, geger, gemarang, mejayan, wonoasri, dan wungu.

\section{b. Desain Pelaksanaan}

Desain kegiatan IPTEK Bagi Masyarakat $\left(\mathrm{I}_{b} \mathrm{M}\right)$ ini dibagi menjadi 4 (empat) kegiatan utama yaitu (1) Analisis Situasi, (2) Persiapan, (3) Pelatihan, (4) Pembimbingan, dan (5) Penentuan Ketercapaian Indikator Keberhasilan/ Target Kegiatan. Pada kegiatan analisis situasi, tim pelaksana melakukan kegiatan awal berupa penyebaran kuesioner dan interview untuk mengetahui berbagai masalah yang dihadapi oleh guru anggota MGMP. Selain itu, hasil kuesioner dan interview dianalisis, dan dideskripsikan untuk penyususnan proposal kegiatan MGMP pada dinas pendidikan (Dindik) kabupaten madiun. Pada tahap persiapan, tim pengusul menyusun kerjasama dengan kelompok MGMP, dan juga membahas detail pelaksanaan kegiatan tersebut. Kerjasama dan ijin pelaksanaan ke dinas juga diurus. Pada tahap pelatihan, tim melakukan pelatihan berupa pemamaparan metode pembelajaran, diskusi cara penerapan metode dalam pembelajaran, dan praktik sekilas beberapa metode. Pada tahap pembimbingan, guru memilih berbagai metode yang dirasa cocok untuk masing-masing; guru menentukan tujuan pembelajaran, indikator pembelajaran, dan materi ajar sesuai dengan skill yang akan diajarkan; guru mendesain pembelajaran dengan mengintegrasikan tujuan, indikator, materi, dan metode pembelajaran; guru mengadakan bimbingan dengan tim pelaksana (dosen); guru mempresentasikan dan mempraktikkan hasil bimbingan di kegiatan MGMP sebagai kegiatan sharing dan penambahan pengetahuan satu dengan yang lain; dan guru memperoleh feedback dari teman sejawat dan dosen perihal presentasi dan implementasi. Pada tahapan terakhir yang berupa penentuan indikator keberhasilan/ target kegiatan, tim pelaksana (dosen) menganalisis semua kegiatan yang telah dilakukan untuk mengetahui apakah taget kegiatan sebagaimana diharapkan sudah tercapai. Pada tahapan ini juga dirumuskan berbagai kendala yang mungkin muncul guna penentuan kegiatan abdimas lanjutan.

Dari paparan desain tersebut, desain pelaksanaan bisa dibagankan sebagai berikut: 
TAHAP ANALISIS SITUASI

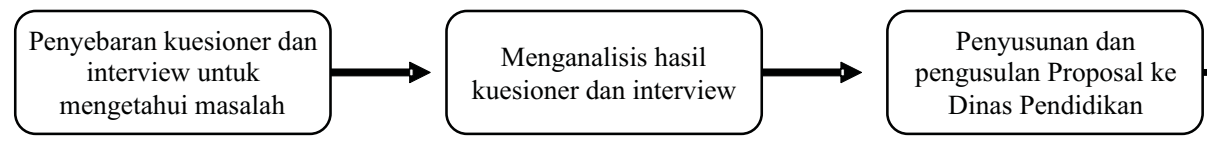

TAHAP PERSIAPAN

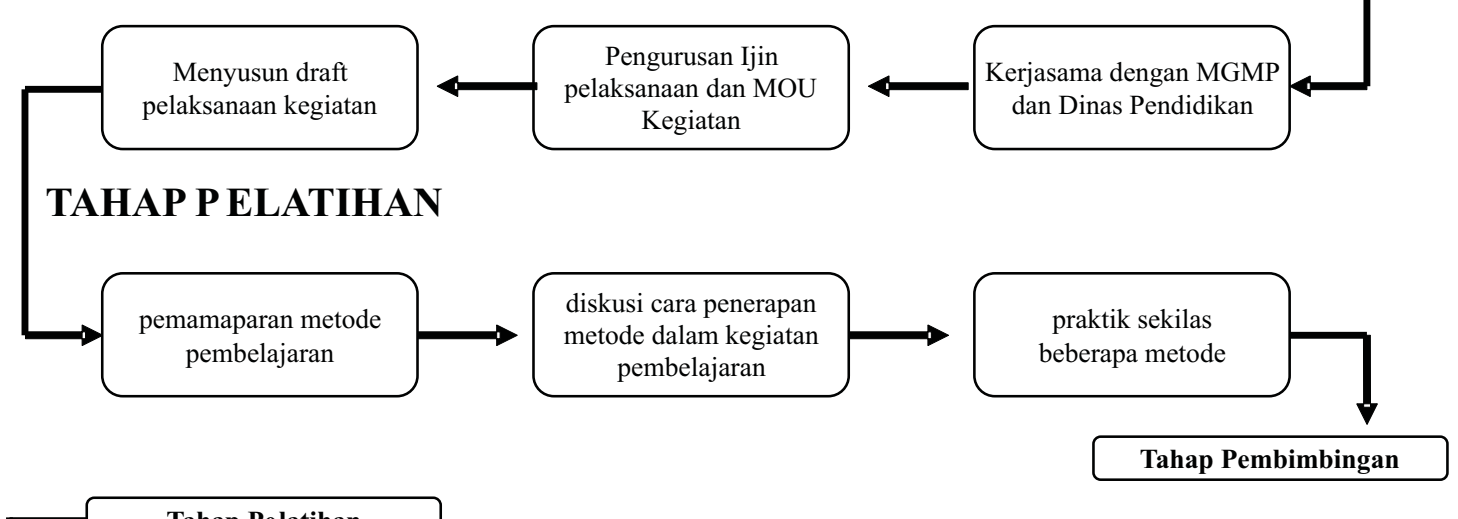

Tahap Pelatihan

\section{TAHAP P EMBIMBINGAN}

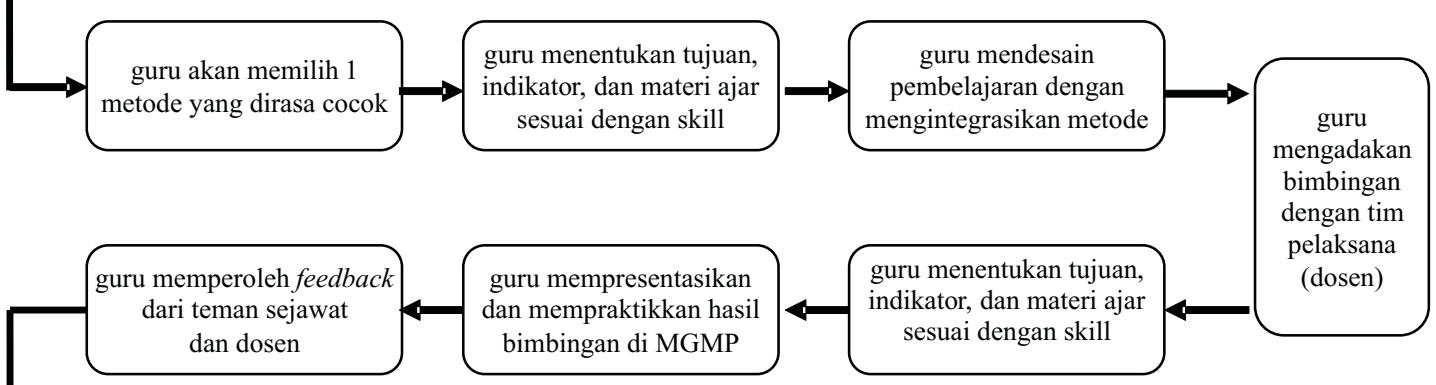

\section{TAHAP PENENTUAN INDIKATOR KEBERHASILAN/ TARGET KEGIATAN}

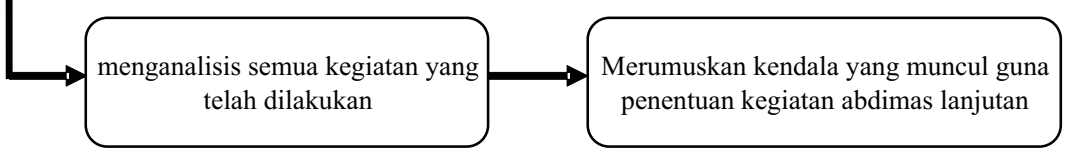

\section{HASIL DAN PEMBAHASAN}

\section{a. Analisis Situasi}

Berdasarkan hasil observasi peneliti dan wawancara dengan para guru Bahasa Inggris tingkat Tsanawiyah se-Kabupaten Madiun, pelatihan pembuatan dan pengaplikasian metode pembelajaran belum terlalu banyak dilaksanakan.

Workshop maupun seminar yang pernah diadakan hanya penyampaian sekilas dari teman sejwat yang sifatnya tidak menyeluruh dan detail. Hal ini menyebabkan materi yang diterima juga sangat terbatas, belum lagi munculnya kesan saling "sungkan" untuk bertanya dan menjawab karena faktor merasa tidak lebih pintar dari yang lain. Ditambahkan,
Praktik implementasi berbagai metode juga tidak pernah dilakukan dengan alasan tidak adanya "ahli" yang mampu memberikan bimbingan dan feedback seputar praktik tersebut. Berdasarkan rangkaian permasalahn tersebut para guru masih butuh bimbingan secara intensif dari "ahli" dalam hal ini dosen perguruan tinggi untuk bisa mencapai tujuan pembelajaran dengan baik.

\section{b. Persiapan}

Sehubungan dengan analisis situasi permasalahan mitra sebagaimana dipaparkan, maka peneliti melakukan langkah dengan membuat program pelatihan yang akan dilengkapi pendampingan kepada guru anggota 
MGMP Bahasa Inggris Madrasah Tsanawiyah (MTs) Se-Kabupaten Madiun. Dalam fase persiapan ini peneliti membuat kesepakatan melalui kontrak kerjasama dan menyusun rancangan kegiatan. Untuk legalitas kegiatan tersebut maka peneliti melakukan koordinasi dengan departemen agama kabupaten Madiun. Gayung bersambut, pihak departemen agama sangat antusias menyambut kegiatan berkesinambungan ini, dan berencana mengadakan agenda rutin pelatihan dan workshop untuk beberapa pertemuan. Para guru juga dikumpulkan oleh ketua MGMP untuk diakomodir, baik dari Madrasah Tsanawiah negeri maupun Swasta di lingkup kabupaten Madiun. Hasil persiapan juga memutuskan bahwasanya kegiatan akan dilaksanakan di MTsN Bibrik Kec. Jiwan Kab. Madiun.

\section{c. Pelatihan}

Dalam pelatihan ini, tim (Sigit Ricahyono, S.S., M.Pd., dan Samsul Arifin, S.Pd.. M.Pd) dibantu oleh seorang pakar metode pembelajaran yang bernama "Heny Sulistyorini, S.Pd., M.Pd". Pakar ini adalah salah seorang dosen terbang di IKIP PGRI Madiun yang juga menyabet gelar guru berprestasi se-kabupaten Madiun dan mewakili kabupaten Madiun untuk pemilihan guru berprestasi tingkat propinsi dan nasional. Pelatihan diawali dengan pemaparan tentang hakikat metode pembelajaran dan hubungannya dengan post method era serta perlunya kreatifitas guru. Dalam pemaparan materi, peserta dibuka pola pikirnya bahwasanya seorang guru yang hebat harus berfikir kritis dan kreatif dalam penyampaian materi pembelajarannya. Para guru dituntut memahami karakter peserta didiknya yang bervariasi dan mampu memilih serta mengaplikasikan metode yang cocok dengan karakter mereka tersebut. Kegiatan dilanjutkan dengan diskusi cara menerapkan berbagai metode tersebut serta variasi penggunaannya apabila terjadi ketidaksesuaian dengan rencana awal. Pada tahap ini peserta juga melakukan praktik cara mengajar dengan menggunakan metode yang diajarkan dalam kelompok kecil. Dalam proses preentasi, peserta terlihat sangat antusias mengimplementasikan bahan pelatihan. Pelaksanaan program pelatihan ini diikuti 20 guru, dimulai pukul 10.00 sampai dengan pukul 14.00 tepat nya hari selasa, 29 April 2014.

\section{d. Pembimbingan}

Tahapan pembimbingan dilaksanakan pasca pelatihan. Pada tahapan ini, guru menyusun suatu rencana pelaksanaan pembelajaran secara individu di sekolah masingmasing. Metode yang mereka dapat disusun secara individu di sekolah dan dikonsultasikan ke dosen ahli dalam hal ini tim (Sigit Ricahyono, S.S., M.Pd., dan Samsul Arifin, S.Pd.. M.Pd). Proses pembimbingan berjalan lancar, meskipun ada beberapa masalah kecil yang muncul. Masalah tersebut yaitu kreatifitas dalam memberikan variasi dari langkah pakem tiap metode pembelajaran tersebut belum dilakukan secara sempurna, Guru masih canggung saat mencoba di kelas masing-masing, guru merasa siswanya perlu dibiasakan dulu dengan pola pembelajaran yang baru dimana tidak seslalu mengerjakan latihan soal di lembar kerja siswa, guru merasa tidak bisa menerapkan semua metode yang dipelajari dalam pola pelatihan karena karakter peserta didiknya yang bermacam-macam, dan beberapa kreatifitas implementasi dari metode- metode pembelajaran tersebut membutuhkan biaya yang tidak sedikit dan prasarana penunjang sekolah yang mewadahi. Pelaksanaan pembimbingan ini dimulai bulan mei 2014 sampai dengan Juni 2014.

\section{e. Penentuan Ketercapaian Indikator Target Kegiatan}

Proses pelatihan dan pembimbingan pada kegiatan ini masih harus dilakukan perbaikanperbaikan. Beberapa perbaikan yaitu waktu pelatihan sebaiknya dibuat lebih lama dan terjadwal secara rutin guna meningkatkan kompetensi guru secara bertahap, pola pelatihan sebaiknya dibuat dengan materi yang tidak terlaku banyak sehingga tidak mengalami "overload" pemahaman materi, dan pembimbingan sebaiknya lebih intensif lagi melalui forum-forum tatap muka sehingga tidak perlu menjelaskan cara mengatasi masalah yang sama pada guru yang berbeda.

\section{DOKUMENTASI KEGIATAN}

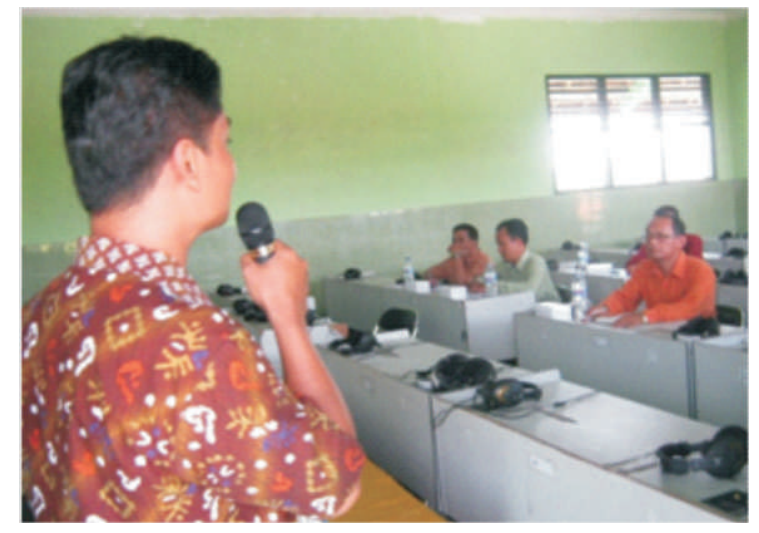




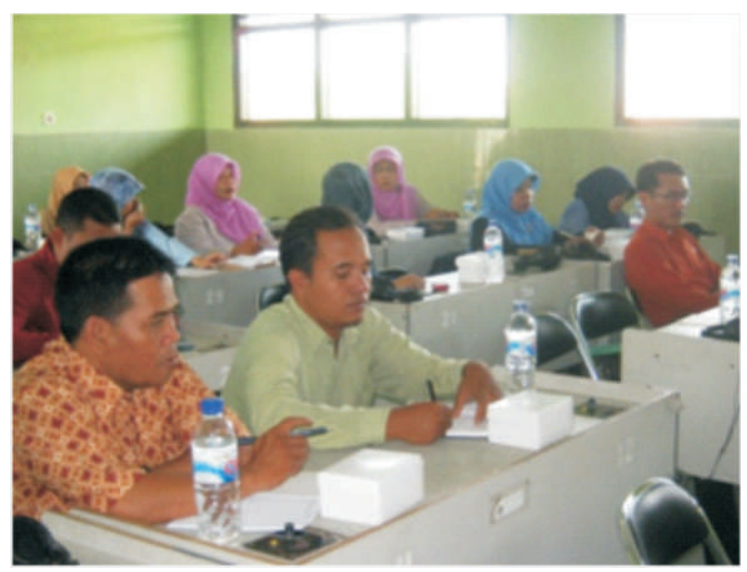

\section{REFERENSI}

Bafadal, I. (2003). Peningkatan Profesional Guru SD. Jakarta: Bumi Aksara.

Depdiknas. (2005). Undang Undang Republik Indonesia tentang Guru dan Dosen Nomer 14 tahun 2005. Jakarta: Depdiknas RI

Sanjaya, W. (2006). Strategi Pembelajaran. Jakarta: Media Abadi.

Saud, U. S. (2009). Pengembangan Profesi Guru. Bandung: CV. Alfabeta.

Soetjipto, dan Kosasi, R. (2004). Profesi Keguruan. Jakarta: Rineka Cipta

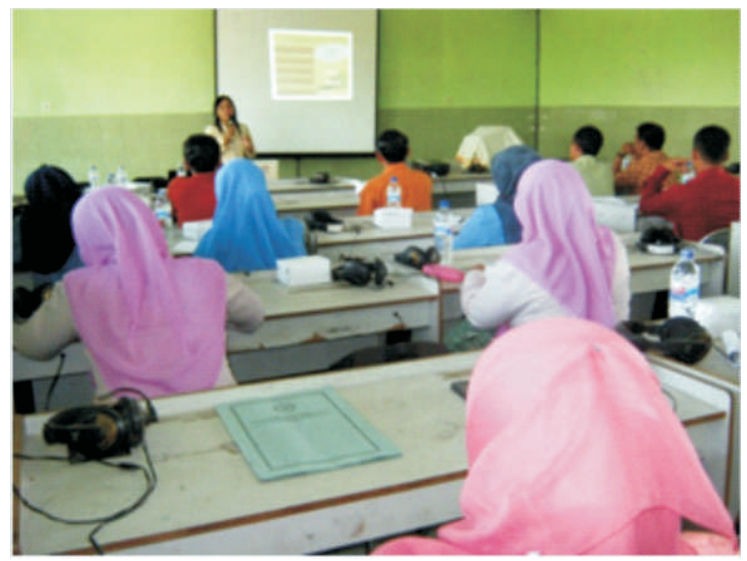

